\title{
ASSESSMENT OF THE LEVEL OF WCAG 2.0 ACCESSIBILITY STANDARD APPLICATION BY SELECTED COMPANIES OF THE POLISH E-COMMERCE SECTOR IN 2015-2019
}

\author{
Anna Mikhalchyk \\ Olsztyn University, Olsztyn, Poland
}

\begin{abstract}
Summary. Internet commerce and internet trade are modern business tools that provide rapid growth in sales of goods. Therefore, a large number of industrial and commercial enterprises seek to sale their goods, works and services through internet commerce and internet trade. The popularity of e-commerce is increasing: in fact, this method of sales is convenient for both merchants and buyers. However, legal support for e-commerce is often a problem, as it's governed by a number of general documents. In turn, internet trade fits into the concept of «e-commerce», which is defined as profit-seeking relationships arising from the acquisition, alteration or termination of civil rights and obligations remotely utilized by information and telecommunication systems, resulting in the fact that participants of such relationships gain property rights and obligations. The online store is a way of presenting or selling products, works or services by the online transaction. The seller of goods, works, services in e-commerce in the course of activity and in the case of distribution of commercial electronic message is obliged to provide direct, simple, stable access of other participants to information in the sphere of e-commerce. The author of this paper article tries to answer the following questions: to what extent do online stores run by selected companies of Polish e-commerce industry meet the requirements of WCAG 2.0 availability standard; what was the impact of changes in the content and construction of e-store unavailability in 2015-2019? The results of monitoring the availability of selected e-stores carried out in 2015-2019 using Utilitia accessibility validator are presented in this paper. The paper is particularly relevant to economists, experts and students.
\end{abstract}

Key words: e-commerce, WCAG 2.0 availability standard.

https://doi.org/10.33108/galicianvisnyk_tntu2020.01.030

Received 15.02.2020

\section{УДК 004.5, 339.1}

\section{ОЦІНЮВАННЯ РІВНЯ ЗАСТОСУВАННЯ СТАНДАРТУ ДОСТУПНОСТІ WСАG 2.0 ВИБРАНИМИ КОМПАНІЯМИ ПОЛЬСЬКОГО СЕКТОРА Е-КОМЕРЦЇ̈ В 2015-2019 РОКИ}

\author{
Анна Михальчик \\ Ольштинський університет, Ольштин, Польщุа
}

\begin{abstract}
Резюме. Інтернет-комериія та Інтернет-торгівля - ие сучасні інструменти бізнесу, які забезпечують швидке зростання продажу товарів. У зв'язку з ичим велика кількість промислових $i$ комериійних підприсмств прагнуть продавати свої товари, роботи й послуги через Інтернет-комериію та Інтернет-торгівлю. Популярність електронної комериї зростає: насправді ией спосіб продажу зручний як для продавців, так і для покупців. Однак юридична підтримка електронної комериії часто стає проблемою, оскільки регулюється низкою загальних документів. У свою чергу, Інтернет-торгівля входить до поняття «електронна комериія», яке визначається як пошук відносин, які є прибутковими, і виникають внаслідок придбання, зміни або припинення цивільних прав та обов'язків, які виконуються дистанційно за допомогою інформаційно-телекомунікаційних систем, унаслідок чого учасники таких відносини отримують майнові права та обов'язки. Інтернет-магазин- ие спосіб представлення або продажу товарів, робіт чи послуг через онлайн-трансакцію. Продавець товарів, робіт, послуг через електронну
\end{abstract}


торгівлю в прочесі своєї діяльності та у разі розповсюдження комериійного електронного повідомлення зобов'язаний забезпечити прямий, простий, стабільний доступ інших учасників до інформації у сфері електронної торгівлі. Ззроблено спроби відповісти на питання: наскільки інтернет-магазини, якими керують вибрані компанії з польської індустрії електронної комериї, відповідають вимогам стандарту доступності WCAG 2.0; яким був вплив змін на зміст і створення доступності електронного магазину у 2015-2019 роках? Представлено результати моніторингу наявності вибраних електронних магазинів, проведеного у 2015-2019 роках із застосуванням валідатора доступності Utilitia.

Ключові слова: електронна комериія, стандарт доступності WCAG 2.0

Presentation of the problem. With the development of digital economy, the implementation of the idea of the Internet accessible to everyone is becoming increasingly important. Accessibility involves removing barriers which prevent the use of websites. This is connected with the necessity of constructing websites and putting content in accordance with the guidelines of the WCAG 2.0 standard (Web Content Accessibility Guidelines). This standard defines the rules the fulfillment of which will allow all users to use a website, regardless of the used equipment, software or disability. A regulation implemented in 2015 in Poland [8] requires websites of public entities to comply with WCAG 2.0 guidelines at the AA level. Since May 2019, this right has been strengthened [9] by introducing mechanisms to effectively enforce the rules of the WCAG 2.1 standard. In 2015-2019, there was no law in Poland regulating the issues of digital accessibility of websites operated by business entities, including these from the e-commerce industry. In 2015, the author conducted research on the level of availability of online stores run by selected companies from the Polish e-commerce industry. The results of the research are presented in the article [6]. The conclusion of the study was the need to monitor the level of availability of selected e-stores, hence the research questions were posed: To what extent do online stores run by selected companies from the Polish e-commerce industry meet the requirements of the WCAG 2.0 accessibility standard? What was the impact of the changes in the content and construction of e-stores on availability in 2015-2019? In order to answer these questions, the author monitored the level of application of the WCAG 2.0 standard by selected companies in 2015-2019 in accordance with the methodology provided.

Review of the literature. In Poland, the issue of digital availability in accordance with the WCAG 2.0 standard is still important. This is due to the development of IT in the area of UX (User Experience [7]) and the development of electronic economy in legal, technical and economic aspects. This is evidenced by legislative initiatives $[8,9]$, activities undertaken by organizations such as the FundacjaWidzialni (http://www.widzialni.org/) [1] and the conducted scientific research, eg [3, 4, 5, 6]. The WCAG 2.0 standard [12] contains recommendations for creating accessible websites. This document provides 4 principles of accessibility: visibility, functionality, intelligibility/transparency, reliability. Guidelines have been defined for each principle (12 in total) and measurable success criteria (61 in total) have been developed for them at 3 levels (A-basic, AA-good, AAA-full) [3, 12]. This makes it possible to check whether there is a compliance of a given website with guidelines at a certain level. The web accessibility level can be checked using validators, i.e. programmes that check the correctness of a document with a specific syntax, e.g. Wave (http://wave.webaim.org/), Total Validator (https://www.totalvalidator.com/), Utilitia (http://www.utilitia.pl/), t.a.w. (http://www.tawdis.net/). With the use of a specific tool it is possible to easily check how correct the structure of the examined website is, to what extent it meets the requirements imposed by the WCAG 2.0 standard and at what level. No error indication by the accessibility validator suggests that the website is available within the WCAG 2.0 standard at a certain level. However, certainty can only be obtained after commissioning the availability audit service and 
obtaining a certificate confirming this fact. On the Polish market there are entities that provide such services, e. g. FundacjaWidzialni (TheVisible Foundation) [1].

In business practice, there are more and more websites with so-called accessibility statements. These are both websites run by public entities and business entities. Public entities in Poland are required to do so by law while commercial companies are encouraged by business benefits associated with it. The literature on the subject $[7,13]$ lists the following benefits: (1) the possibility of acquiring new customers by increasing the level of reaching customers, (2) expanding the sales market, (3) image benefits, (4) better positioning in search engines, because a significant part of WCAG 2.0 assumptions overlap with good SEO practices (Search Engine Optimization), which in turn translates into an increase in the company's competitiveness. This may be relevant for online sales companies. In Poland, the e-commerce market is growing rapidly. The entity representing the Polish e-commerce industry is the Chamber of Electronic Economy(Izba Gospodarki Elektronicznej) - «e-Chamber» (https://eizbpl/), which brings together entities specializing in various branches of the e-commerce industry such as retailers (B2C), e-commerce platforms (B2C, C2C, B2B), online payments [2].

Methodology. The study poses the following research questions: To what extent do online stores run by selected companies from the Polish e-commerce industry meet the requirements of the WCAG 2.0 accessibility standard? What was the impact of changes in the content and construction of the service on availability in 2015-2019? In order toobtain answers to these questionsthe research in two stages was required covering the scope: (1) selection of companies from the Polish e-commerce industry running online stores in $\mathrm{B} 2 \mathrm{C}$ relationship; (2) recognition of the possibility of operation and use of the availability validator on the example of the Utilitia service [11]; (3) analyzing and assessing the level of availability of online stores of selected companies from the Polish e-commerce industry using the Utilitia availability validator in 2015-2019. Stage I covered the scope of work (1), (2) and (3) and was carried out in 2015. Stage II included works (3) carried out in 2017, 2018 and 2019.

The subject of the study was 20 online stores run by companies that are members of the «e-Chamber» in 2015. The subject of the study was the degree of compliance with the availability standard of WCAG 2.0. The study was conducted using the Utilitia validator [11] in the following timeframes: Stage I- October 2015; Stage II - 2017; November 2018, December 2019.

Information sources which were used included scientific articles, reports, websites, online knowledge bases, information materials provided by the software producer and obtained primary data.

Results. Stage I. In 2015, after analyzing the catalog of companies [2], a research group of 20 companies was selected; these were retailers conducting business in B2C relationship by running an online store. Each company was assigned a different identifier from S01 to S20, which at the same time identified the e-store run by a company. Next, the research concerned the possibilities of operation and use of the Utilitia validator and the interpretation of the feedback obtained in the form of a report and assessment of the degree (level) of compliance with the WCAG 2.0 availability standard on a scale from 0 to 10 . The rating from 7 to 10 means that a site meets the accessibility standards, rating from 5.1 to 6.9 - website partly meets accessibility standards, rating from 0 to 5 - website does not meet accessibility standards. The author carried out 20 analyzes of the availability of 20 websites - e-stores. Out of 20 analyses, 19 were technically correct and the result of the evaluation was returned. In 1 case, the validator returned technical error information, did not perform the analysis and did not issue an assessment. The following results were obtained: 6 cases - a website meets accessibility standards, 10 cases - a site partly meets accessibility standards, 3 cases - a website does not meet accessibility standards. Detailed research results and the conclusions are presented in the article [6]. 
Research results. Stage II. In 2017, 2018 and 2019, 60 availability analyses of 20 selected e-stores were conducted with the use of the Utilitia validator. The table below summarizes the results of the degree of compliance of e-stores with the WCAG 2.0 standard in 2017, 2018, 2019, compared to the results from 2015.

\begin{tabular}{|c|c|c|c|c|c|c|c|c|c|c|c|c|c|c|c|c|c|c|c|c|}
\hline & $\mathbf{S 1 3}$ & $\mathbf{S 0 8}$ & $\mathbf{S 0 5}$ & $\mathbf{S 1 7}$ & $\mathbf{S 0 4}$ & $\mathbf{S 2 0}$ & $\mathbf{S 0 2}$ & $\mathbf{S 1 1}$ & $\mathbf{S 0 6}$ & $\mathbf{S 1 8}$ & $\mathbf{S 1 4}$ & $\mathbf{S 1 6}$ & $\mathbf{S 1 9}$ & $\mathbf{S 1 0}$ & $\mathbf{S 0 9}$ & $\mathbf{S 0 1}$ & $\mathbf{S 1 2}$ & $\mathbf{S 1 5}$ & $\mathbf{S 0 3}$ & $\mathbf{S 0 7}$ \\
\hline $\mathbf{2 0 1 5}$ & $\mathbf{8 , 2}$ & 5,9 & & 6,4 & 4,4 & 6,5 & $\mathbf{4 , 8}$ & $\mathbf{7 , 5}$ & 6,9 & 5,2 & 5,5 & 5,9 & $\mathbf{7 , 0}$ & $\mathbf{8 , 8}$ & 6,6 & $\mathbf{7 , 8}$ & 6,3 & 4,9 & $\mathbf{9 , 4}$ & 6,0 \\
\hline $\mathbf{2 0 1 7}$ & $\mathbf{8 , 3}$ & & & 6,4 & 6,0 & & 6,4 & 6,8 & & 6,5 & 5,4 & 6,9 & 6,1 & & 6,1 & $\mathbf{7 , 0}$ & & 5,5 & & \\
\hline $\mathbf{2 0 1 8}$ & $\mathbf{8 , 3}$ & $\mathbf{7 , 8}$ & $\mathbf{7 , 5}$ & 6,4 & 6,5 & 6,9 & 6,4 & 6,8 & & 6,0 & 6,3 & 6,4 & 5,5 & 5,5 & $\mathbf{4 , 9}$ & $\mathbf{8 , 0}$ & 5,9 & 5,4 & $\mathbf{9 , 3}$ & \\
\hline $\mathbf{2 0 1 9}$ & $\mathbf{8 , 8}$ & $\mathbf{8 , 6}$ & $\mathbf{7 , 5}$ & $\mathbf{7 , 3}$ & $\mathbf{7 , 1}$ & 6,9 & 6,9 & 6,8 & 6,7 & 6,5 & 6,4 & 6,0 & 5,9 & 5,5 & 5,5 & & & & $\mathbf{x}$ & $\mathbf{x}$ \\
\hline \multicolumn{8}{|c}{ i } \\
\hline
\end{tabular}

Figure 1. Results of compliance with WCAG 2.0 in 2015-2019 (validator Utilitia)

Source: own study.

The data in the table is in descending order of 2019 for the current availability ranking. 3 color classification websites were used: green - a site meets accessibility standards (rating from 7 to 10), yellow - a site partially meets accessibility standards (rating from 5.1 to 6.9), red - a website does not meet accessibility standards (rating from 0 to 5). The blanks mean that the validator returned information about an error in loading the website, did not carry out the analysis and did not issue an assessment. Stores that were no longer on the Internet in 2019 were marked with an x. Arrow icons indicate an increase (green arrow), no change (yellow arrow) and a decrease (red arrow) in the level of availability compared to previous results. After comparative analysis it can be stated that in 2019 in 6 cases of operating e-storesthe level of availability increased, in 3 cases it decreased, and in 6cases the availability did not change, in 3 cases it is difficult to say.

In 2019 , in 5 cases the degree of accessibility ranged from 7.1 to 8.8 points on the validator scale and a message was issued confirming that the analyzed website meets the selected accessibility criteria. In 10 cases, the obtained scores were in the range from 5.5 to 6.9 , which means that the analyzed e-stores meet only a part of the selected accessibility criteria. In 3 cases, the validator returned technical error information and did not carry out the analysis. Ranking of the availability level of selected e-stores belonging to companies associated in the Chamber of Electronic Economy representing e-commerce in Poland is presented in Figure 2 below.

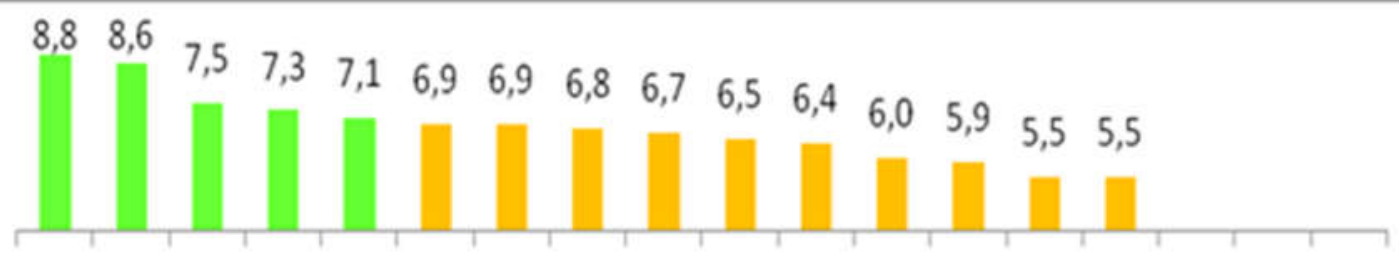

S13 S08 S05 S17 S04 S20 S02 S11 S06 S18 S14 S16 S19 S10 S09 S01 S12 S15

Figure 2. Ranking of compliance of WCAG 2.1 e-stores in 2019 (validator Utilitia)

Source: own study. 
Based on the review of the generated final analysis reports, it can be concluded that in the case of sites that meet the accessibility criteria, the most common cause of errors are semantic irregularities of the HTML, CSS code. In other cases, other irregularities are additionally present to varying degrees.

Conclusions. The following conclusions can be made on the basis of the obtained results:

1. In 2019, all investigated e-stores met the accessibility criteria in accordance with the international WCAG 2.0 standard, but mainly to a partial extent, which means that the idea of digital accessibility was consistently implemented.

2. The results of research from subsequent years showed small but gradual progress of the availability degree.

3. While creating e-store or updating its content, the guidelines set out in WCAG 2.0 standard were taken into account to a small extent having negative impact on competitiveness and revenues from business operations.

\section{References}

1. Fundacja Widzialni. URL: http://www.widzialni.org/.

2. Izba Gospodarki Elektroniczneje-Commerce Polska, e-Commerce Polska - KATALOG firm i usług. URL: http://www.ecommercepolska.pl/files/2414/4239/3789/Katalog_firm_i_uslug_ecommercepolska. pdf.

3. Krawiec $€$. Analiza poziomu dostępności serwisów WWW w kontekście promocji i dystrybucji na przykładzie wybranych ogólnopolskich sklepów komputerowych. Marketing i Rynek. 2017. URL: https://www.wir.ue.wroc.pl/info/article/WUT15c2754280a94ed2a9e1c5b77elb4b13/\#.XiS04chKhPY.

4. Marcinkowski P., Luboń M., Raport dostępności 2019. Wybrane podmioty realizujące zadania publiczne. URL: http://www.widzialni.org/container/raport-dostepnosci-2019.pdf.

5. Michalczyk A. Tworzenie stron internetowych dostępnych dla niepełnosprawnych użytkowników zgodnie z wytycznymi WCAG 2.0 / red. Chmielarz W., Kisielnicki J., Parys T. Informatyka w społeczeństwie informacyjnym. 30 lat Informatyki na Wydziale Zarządzania UW. Warszawa: Wydawnictwo Naukowe Wydziału Zarządzania Uniwersytetu Warszawskiego, 2015. P. 119-131. URL: http://www.wz.uw.edu.pl/portaleFiles/6133-wydawnictwo-/Informatyka_w_spo\%C5\%82ecze\%C5\%84 stwie_informacyjnym.pdf.

6. Michalczyk A. Assessment the web accessibility of e-shops of selected polish e-commerce companies, Socio-Economic Problems and the State. ISSN 2223-3822. Vol. 13. No. 2. November 2015. P. 16-21. URL: https://sepd.tntu.edu.ua/images/stories/pdf/2015/15maapcc.pdf.

7. Ritter M., Winterbottom C. UX w projektowaniu witryn internetowych. Helion, 2018.

8. Rozporządzenie Rady Ministrów z dnia 12 kwietnia 2012 r. w sprawie Krajowych Ram Interoperacyjności, minimalnych wymagań dla rejestrów publicznych i wymiany informacji w postaci elektronicznej oraz minimalnych wymagań dla systemów teleinformatycznych. (Dz. U. 2012, pozycja 526).

9. Ustawa z dnia 4 kwietnia 2019 r. o dostępności cyfrowej stron internetowych i aplikacji mobilnych podmiotów publicznych. (Dz.U. 2019 poz. 848).

10. Utilitia S. A. URL: http://utilitia.pl/.

11. Walidator Utilitia. URL: https://validator.utilitia.pl/analyses/new.

12. W3C. Web Content Accessibility Guidelines (WCAG) Overview. URL: https://www.w3.org/WAI/ standards-guidelines/wcag/.

13. W3C. Outdated incomplete draft of auxiliary benefits of accessible web design. URL: http:// www.w3.org/WAI/bcase/benefits.html. 